\title{
The roles of urine interleukin-13, CD80, CD28, matrix metalloproteinase-2 and granzyme $B$ in the pathogenesis of childhood minimal change nephrotic syndrome
}

\author{
Idrar interlökin-13, CD80, CD28, matriks metaloproteinaz-2 ve granzim B'nin çocukluk çağı \\ minimal değişim nefrotik sendrom patogenezindeki rolleri
}

Cengiz Zeybek ${ }^{1}$, Duygu Övünç Hacıhamdioğlu¹, Süleyman Tolga Yavuz², Aysel Pekel ${ }^{3}$, Cihangir Akgün ${ }^{4}$ Burcu Bulum ${ }^{5}$, Kaan Gülleroğlu ${ }^{6}$, Aslı Kantar ${ }^{6}$, Aslı Kavaz ${ }^{5}$ Uğur Muşabak , Fatoş Yalçınkaya ${ }^{8}$, Esra Baskın ${ }^{9}$, Faysal Gök ${ }^{10}$

\begin{abstract}
Objective: Minimal change disease (MCD) is the most common cause of nephrotic syndrome in childhood but its pathogenesis remains poorly understood. A T-cell-derived factor or factors were initially alleged as contributing to the disease pathogenesis. However, podocyte CD80 expression is now a commonly discussed theory. The aim of this study was to investigate the pathogenesis of MCD by determining urine interleukin-13, CD80, CD28, matrix metalloproteinase-2 (MMP-2), and granzyme $B$ levels.
\end{abstract}

Methods: Thirty patients and thirty healthy children were evaluated in this study. Six patients had biopsy proven MCD. The remaining patients were considered to have MCD because of their age at time of diagnosis; response to steroid treatment, absence of gross hematuria, hypocomplementemia or renal failure; and normal blood pressures in the active stage. The nephrotic-phase urine interleukin-13, CD80, CD28, MMP-2, and granzyme $B$ levels of all patients were compared with the remission-stage urine levels of the same patients and control subjects. The urine samples were collected immediately before the application of immunosuppressive drugs or other treatment modalities.

Results: Significantly higher interleukin-13, CD80, CD28, and MMP-2 levels were observed in the relapse period compared with both the remission period and control subjects. There was a significant positive correlation between the active-stage urine interleukin-13 and CD80 levels ( $r=0.619, p<0.001)$.

Conclusion: Interleukin-13, CD80, CD28, and MMP-2 seem to have roles in the pathogenesis of MCD and using inhibitors of these molecules in treatment of steroid and immunosuppressive-resistant MCD cases can be thought. J Clin Exp Invest 2014; 5 (3): 354-361

Key words: Minimal change disease, Interleukin-13, B7 proteins, MMP-2, granzyme B

\section{ÖZET}

Amaç: Minimal değişiklik hastalığı çocuklarda nefrotik sendromun en sık nedenidir ve patogenezi hala aydınlatılamamıştır. Başlangıçta T hücresi kaynaklı faktör ya da faktörlerin hastalığın patogenezinden sorumlu olduğu ileri sürülmüştür. Fakat günümüzde hastalığın patogenezinde podosit CD80 ekspresyonu ön plana çıkmıştır. Bizim bu çalışmada amacımız hastaların idrar interlökin-13, CD80, CD28, matriks metaloproteinaz-2 ve granzim b düzeylerine bakarak hastalığın patogenezini anlamaya çalışmaktır.

Yöntemler: Bu amaçla 30 hasta ve 30 sağlıklı çocuktan oluşan kontrol grubu ile çalıştık. 6 hastanın biyopsi sonucu minimal değişiklik hastalığı idi. Diğer hastalara hastalığın ilk aktif dönemindeki başlangıç yaşı, steroid tedavisine verdikleri cevap, hastalığın tanısı sırasında gros hematüri, hipokomplementemi, renal yetmezlik ve hipertansiyon olmaması nedeniyle minimal değişiklik hastalığı tanısı konuldu. Hastaların aktif faz idrar interlökin-13, CD80, CD28, matriks metaloproteinaz-2 ve granzim b düzeyleri aynı hastaların remisyon dönemi ve kontrol grubu ile karşılaştırıldı. İmmünsüpresif ilaçlar ya da diğer tedavi modaliteleri başlamadan hemen önce idrar örnekleri alındı.

Bulgular: Hastalığın aktif döneminde remisyon ve kontrol grubuna göre istatistiksel olarak anlamlı idrar interlökin-13, CD80, CD28 ve MMP-2 yüksekliği saptadık. Nefrotik faz idrar interlökin-13 düzeyleri ile CD80 düzeyleri arasında pozitif korelasyon mevcuttu $(r=0,619, p<0,001)$.

Sonuç: İnterlökin-13, CD80, CD28 ve MMP-2 moleküllerinin minimal değişim hastalığı patogenezinde rolleri olduğu görüldü. Steroide ve immünsüpresiflere dirençli minimal değişim hastalığı tedavisinde bu moleküllerin inhibitörlerinin kullanılması düşünülebilir.

Anahtar kelimeler: Minimal değişiklik hastalığı, interlökin-13, B7 proteinleri, MMP-2, granzim B

${ }^{1}$ Division of Pediatric Nephrology, Department of Pediatrics, Gülhane Military Medical Academy, Ankara, Turkey

${ }^{2}$ Division of Pediatric Immunology-Allergy, Department of Pediatrics, Gülhane Military Medical Academy, Ankara, Turkey

${ }^{3}$ Division of Allergy-Immunology, Department of Internal Medicine, Gülhane Military Medical Academy, Ankara, Turkey

${ }^{4}$ Division of Pediatric Nephrology, Department of Pediatrics, 100.YIl University, Van, Turkey

${ }^{5}$ Division of Pediatric Nephrology, Department of Pediatrics, Ankara University, Ankara, Turkey

${ }^{6}$ Division of Pediatric Nephrology, Department of Pediatrics, Başkent University, Ankara, Turkey

${ }^{7}$ Division of Allergy-Immunology, Department of Internal Medicine, Gülhane Military Medical Academy, Ankara, Turkey

${ }^{8}$ Division of Pediatric Nephrology, Department of Pediatrics, Ankara University, Ankara, Turkey.

${ }^{9}$ Division of Pediatric Nephrology, Department of Pediatrics, Başkent University, Ankara, Turkey

${ }^{10}$ Division of Pediatric Nephrology, Department of Pediatrics, Gulhane Military Medical Academy, Ankara, Turkey

Correspondence: Cengiz Zeybek,

Gülhane Military Medical Academy, Department of Pediatric Nephrology, Ankara, Turkey Email: zeybekcengiz@yahoo.com

Received: 21.05.2014, Accepted: 06.08.2014

Copyright @ JCEI / Journal of Clinical and Experimental Investigations 2014, All rights reserved 


\section{INTRODUCTION}

Minimal change disease (MCD) is the most common cause of nephrotic syndrome in childhood. MCD is characterized by a rapid response to steroid treatment. Therefore, the term "MCD" is generally used as a synonym for steroid-sensitive nephrotic syndrome (SSNS). Idiopathic nephrotic syndrome (INS) is a term that includes all cases of SSNS and steroid- resistant nephrotic syndrome (SRNS) [1].

The hypothesis that MCD involves T-cell dysfunction was introduced by Shalhoub in 1974 [2]. Later, cyclosporine was shown to block interleukin (IL)-2 releases, which is a T-cell cytokine, intensifying the suspicion that $\mathrm{T}$ cells play a role in the pathogenesis of MCD [3]. Although how T cells increase glomerular permeability remains unknown there is some evidence that a factor or factors released from $T$ cells initiate the disease $[4,5]$.

Although controversial, MCD is frequently seen in patients with atopy and allergy [6]. These allergic diseases typically involve a TH2 immunological response. Thus, increased IgE levels, a characteristic $\mathrm{TH} 2$ pattern, have been seen in patients with MCD [7]. IL-13 is an important cytokine that is secreted from $\mathrm{TH} 2$ cells. The importance of $\mathrm{IL}-13$ in the pathogenesis of allergic diseases has been demonstrated previously [8]. IL-13 may also be important in the pathogenesis of MCD [9].

In animal studies, the CD80 molecule has been shown to be prominent in podocytes in pathological conditions such as lipopolysaccharide-induced proteinuria [10]. Increased urinary excretion of CD80 has been shown to be relatively specific for MCD [11]. In fact, it has been asserted that this molecule can be used to distinguish MCD (SSNS) and focal segmental glomerulosclerosis (SRNS) at the time of diagnosis [12].

The CD28 molecule is present on the surface of T cells and is responsible for T-cell activation [13]. The urinary level of the identical molecule CTLA4 , which has an inhibitory effect and is expressed on the surface of $T$ cells has been shown to be decreased during the active stage in with INS, albeit not significantly so [11]. However, the role of CD28 in MCD has not been investigated.

Matrix metalloproteinase-2 (MMP-2) destroys the type-IV collagen molecule, which is the major structural component of the basal membrane, and all MMPs destroy extracellular matrix proteins [14]. The type-IV collagen molecule is present in the glomerular basal membrane, and few studies have evaluated the role of MMP-2 in the pathogenesis of childhood INS. Moreover, most investigated patients were taking immunosuppressive drugs $[15,16]$.

Granzyme B is present in cytotoxic T lymphocytes (CTLs) and natural killer (NK) cells. The most important function of granzyme B is to kill the target cell by stimulating apoptosis together with perforin [17]. Granzyme B is also present in T regulatory (Treg) cells, which are known to be dysfunctional in the active stage of MCD [18]. Granzyme B, which is present in Treg cells, increases the immunosuppressive effects of Treg cells, however, the relationship between granzyme $B$ and nephrotic syndrome is unknown $[19,20]$. Furthermore, it has been shown that the numbers of zeta chains are decreased in NK cells in the active stage of INS [21].

In this study, we evaluated the urine IL-13, granzyme B, CD80, CD28 and MMP-2 levels in children with MCD in both the active (nephrotic) and remission stages. The children were taking no immunosuppressives, including steroids. The levels of all parameters were compared among the children in the patient group as well as with a separate control group. Our aim was to at least partly elucidate the immunopathogenesis of this disease and thus identify potential new treatment modalities.

\section{METHODS}

\section{Patients and study design}

Patients with SSNS, either newly diagnosed or in remission (for at least 2 months), were included in the study. Thirty patients were used in IL-13, CD80; CD28, MMP-2 and granzyme B studies. Three of 30 patients were initial diagnosis of MCD and the other 27 patients were in relapse period while in remission. Thirty healthy children of similar age and sex (no systemic or renal disease as determined by physical examination and laboratory studies) were evaluated in the control group of CD80 study, 19 healthy children were evaluated in the control group of IL-13, CD28, granzyme B, and MMP-2 studies. Informed consent was obtained from the parents of all patients and control subjects.

Six patients had biopsy proven MCD. The remaining were considered to have MCD because of their age at the time of diagnosis; their response to steroid treatment; the absence of gross hematuria, hypocomplementemia, or renal failure; and the presence of a normal blood pressure in the active stage of the disease. 
Active stage urine IL-13, granzyme B, CD80, CD28, and MMP-2 levels of all patients were compared with their levels during remission and those of the control group. No patients in either the active stage or remission were taking any immunosuppressive (including steroids) or other treatments (angiotensin-converting inhibitors, etc.) at the time of urine sample collection. We recruited the same patients who not taking any medications at time of urine sample collection in order to obtain more reliable results.

Relapse of MCD was not associated with infection according to clinical and laboratory examinations.

Nephrotic syndrome was diagnosed according to the outlined by the "International Study of Kidney Diseases in Children" [22].

The patients' glomerular filtration rates were calculated according to the modified Schwartz formula [23].

This study was approved by the Gülhane Military Medical Academy Ethics Committee and performed in compliance with the Declaration of Helsinki.

\section{Urine measurements}

Five-milliliter urine samples were obtained from patients in both the study and the control groups. First-morning urine samples were collected for the determination of cytokines (IL-13) and other markers. Midstream, clean-catch specimens were obtained from children with adequate bladder control. Urine specimen bags were used for children with inadequate bladder control. Following collection, the samples were immediately centrifuged at 1000 rpm for 10 minutes, separated from morphotic elements, frozen in 2-ml aliquots at $-80^{\circ} \mathrm{C}$, and thawed to room temperature immediately prior to analysis.

\section{Enzyme-linked immunosorbent (ELISA) studies}

Urine CD80, CD28, and MMP-2 levels were measured using commercially available ELISA kits from eBioscience (San Diego, CA, USA). The minimum sensitivities of the CD80, CD28, and MMP-2 kits were $0.10,0.18$, and $3.50 \mathrm{ng} / \mathrm{ml}$, respectively.

\section{Cytometric bead array (CBA) studies}

The urine IL-13 and granzyme B levels were measured using commercially available CBA kits from Raybio (Norcross, GA, USA). The minimum sensi- tivities limits of the IL-13 and granzyme B kits were 0.6 , and $4.0 \mathrm{pg} / \mathrm{ml}$, respectively.

The CBA studies were performed according to the relevant literature [24].

\section{Creatinine measurements}

Urine creatinine levels were measured using the modified Jaffe method with an automatic analyzer (Olympus AU 2700; Beckman Coulter, CA, USA). To standardize the samples and avoid dilution effects, $\mathrm{ng} / \mathrm{ml}$ and $\mathrm{pg} / \mathrm{ml}$ values of the urine parameters were divided into urine creatinine values and expressed as "ng/mg creatinine" and "pg/mg creatinine".

\section{Statistical analysis}

The PASW Statistics software package version 18.0 (SPSS Inc., Chicago, IL, USA) was used for all statistical analyses. Categorical and numerical variables were expressed as frequencies and medians (interquartile range) because they did not show a normal distribution. Group comparisons were performed using the Mann-Whitney $U$ test for numerical variables and the chi-square test for categorical variables. The Wilcoxon test was performed to test the significance of pairwise differences. Spearman's correlation coefficient was calculated for comparisons of active-stage urine IL-13, CD80, CD28, MMP-2, and granzyme B levels and between the active-stage IL-13, CD80, CD28, MMP-2, and granzyme $B$ levels and the active stage proteinuria level. A p value of less than 0.05 was regarded as indicative of statistically significant.

\section{RESULTS}

\section{Demographic and biochemical characteristics}

Thirty children diagnosed with MCD (age range, 2-19 years; median, 7.2 years) and 30 healthy children (age range, 3-16 years; median, 7.8 years) were included in this study. There were 12 females and 18 males in the study group and 14 females and 16 males in the control group. No statistically significant differences in age or sex were identified between the study and control groups $(p=0.457$ and $p=0.602$, respectively). In addition to the above age and sex data, the serum albumin, cholesterol, and creatinine levels; estimated creatinine clearance; and proteinuria data are provided in Table 1. The results were expressed as "median (minimum-maximum)". 
As expected, the serum albumin levels of patients with active disease were significantly lower and the serum cholesterol and proteinuria levels were significantly higher than those of patients in remission and control subjects $(p<0.001)$. There were no statistically significant differences in these variables between the remission phase and the control group ( $p>0.05)$. No statistically significant differences in any other parameters were detected among the three groups $(p>0.05)$ (Table 1$)$.

Table 1. Laboratory characteristics of the children with minimal change nephrotic syndrome in the study group and healthy subjects in the control group

\begin{tabular}{|c|c|c|c|c|c|c|}
\hline & \multicolumn{2}{|c|}{ Study Group $(n=30)$} & \multirow{2}{*}{$\begin{array}{c}\text { Control Group }{ }^{c} \\
(n=30)\end{array}$} & \multicolumn{3}{|c|}{ Differences } \\
\hline & Active stage ${ }^{\text {a }}$ & Remission stage $^{b}$ & & $p^{a-c}$ & $p^{a-b}$ & $p^{b-c}$ \\
\hline Serum Albumin, mg/dl & $1.6(1.3-1.9)$ & $4.3(3.8-4.5)$ & $4.5(4.3-4.7)$ & $<0.001$ & $<0.001$ & 0.700 \\
\hline Serum Cholesterol, mg/dl & $401(323-485)$ & $175(158-192)$ & $149(123-171)$ & $<0.001$ & $<0.001$ & 0.202 \\
\hline Serum Creatinine, mg/dl & $0.41(0.29-0.57)$ & $0.51(0.40-0.59)$ & $0.51(0.46-0.61)$ & 0.112 & 0.269 & 0.267 \\
\hline eGFR, $\mathrm{ml} / \mathrm{m} / 1.73 \mathrm{~m}^{2}$ & $131(115-158)$ & $137(115-162)$ & $129(114-139)$ & 0.492 & 0.247 & 0.174 \\
\hline Proteinuria, $\mathrm{mg} / \mathrm{m}^{2} / \mathrm{h}$ & $93.6(76.5-190.2)$ & $3.2(2.7-3.6)$ & $2.7(2.4-3.4)$ & $<0.001$ & $<0.001$ & 0.09 \\
\hline
\end{tabular}

F: Female, M: Male, eGFR: Estimated glomerular filtration rate

\section{IL-13 levels}

The urine IL-13 levels in the active-stage, remission, and control groups were 3.6 (2.1-5.7), $1.6(1.0-2.3)$ and $1.8(1.2-2.9) \mathrm{pg} / \mathrm{mg}$ creatinine, respectively. The urine IL-13 levels in the active-stage group were significantly higher than those in both the remission and control groups $(p<0.001$ and $p=0.004$, respectively). There was no statistically significant difference in the urine IL-13 level between the remission and control groups $(p=0.268)$. The urine IL-13 levels among the three groups are shown in Figure 1.

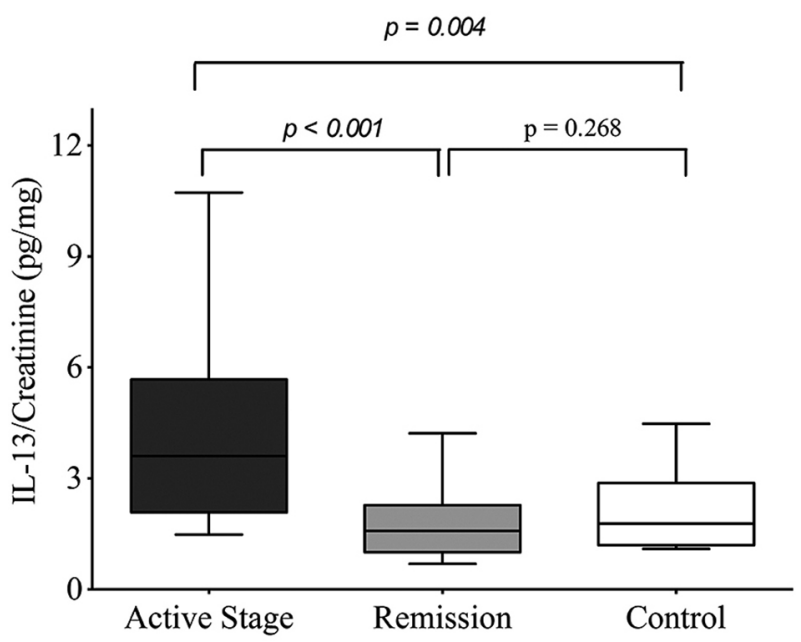

Figure 1. Urinary IL-13 levels of the study and the control groups

\section{CD80 levels}

The urine CD80 levels in the active-stage, remission, and control groups were $0.34(0.18-0.53), 0.18$ $(0.13-0.26)$ and $0.18(0.15-0.31) \mathrm{ng} / \mathrm{mg}$ creatinine, respectively. The urine CD80 levels in the activestage were significantly higher than those in both the remission and control groups $(p=0.001$ and $p=$ 0.02 , respectively). There was no statistically significant difference in the urine CD80 level between the remission and control groups $(p=0.807)$. The urine CD80 levels among the three groups are shown in Figure 2.

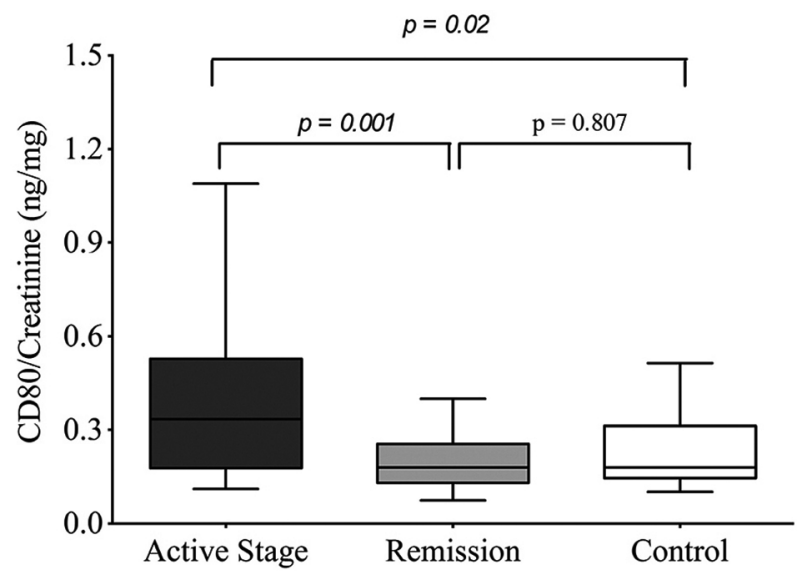

Figure 2. Urinary CD80 levels of the study and the control groups 


\section{CD28 levels}

The urine CD28 levels in the active-stage, remission, and control groups were 2.5 (0.5-4.9), $1.0(0.3-$ $2.2)$ and $1.3(0.9-1.7) \mathrm{ng} / \mathrm{mg}$ creatinine, respectively. The urine CD28 levels in the active-stage were significantly higher than those in both the remission and control groups $(p=0.026$ and $p=0.032$, respectively). There was no statistically significant difference in the urine CD28 level between the remission and control groups $(p=0.659)$. The urine CD28 levels among the three groups are shown in Figure 3.

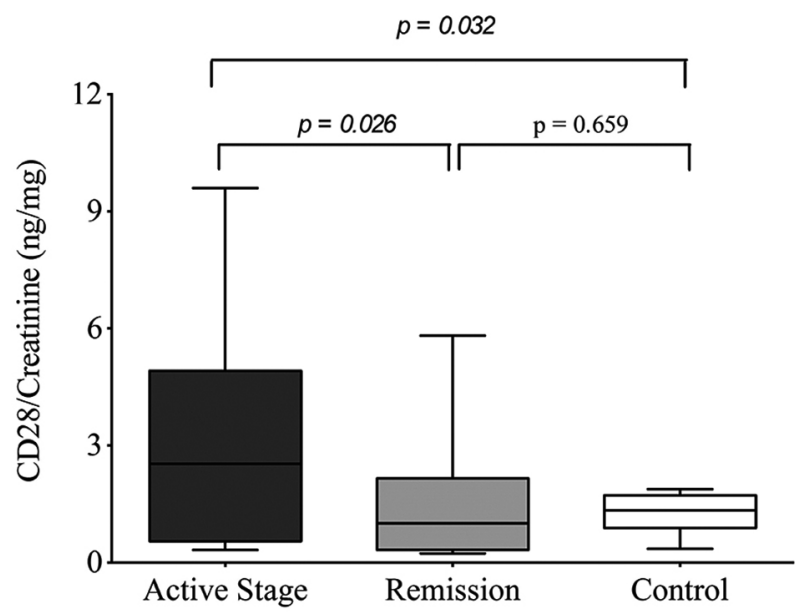

Figure 3. Urinary CD28 levels of the study and the control groups

\section{MMP-2 levels}

The urine MMP-2 levels in the active-stage, remission, and control groups were 16 (5.2-83.5), 4.2 (1.8-11.3) and $3.2(1.7-10.7) \mathrm{ng} / \mathrm{mg}$ creatinine, respectively. The urine MMP-2 levels in the activestage were significantly higher than those in both the remission and control groups $(p=0.001$ and $p=0.001$, respectively). There was no statistically significant difference in the MMP-2 level between the remission and control groups $(p=0.837)$. The urine MMP-2 levels among the three groups are shown in Figure 4.

\section{Granzyme B levels}

The urine granzyme $B$ levels in the active-stage, remission, and control groups were 2.3 (1.3-6.9), 2.1 (0.7-5.4) and 4.6 (0.9-8.6) pg/mg creatinine, respectively. There were no statistically significant differences in the granzyme $B$ level among the three groups. The urine granzyme $B$ levels among the three groups are shown in Figure 5.

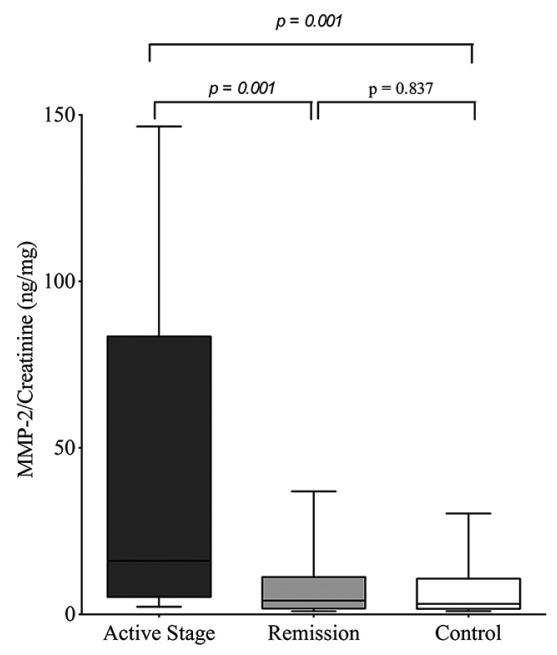

Figure 4. Urinary MMP-2 levels of the study and the control groups

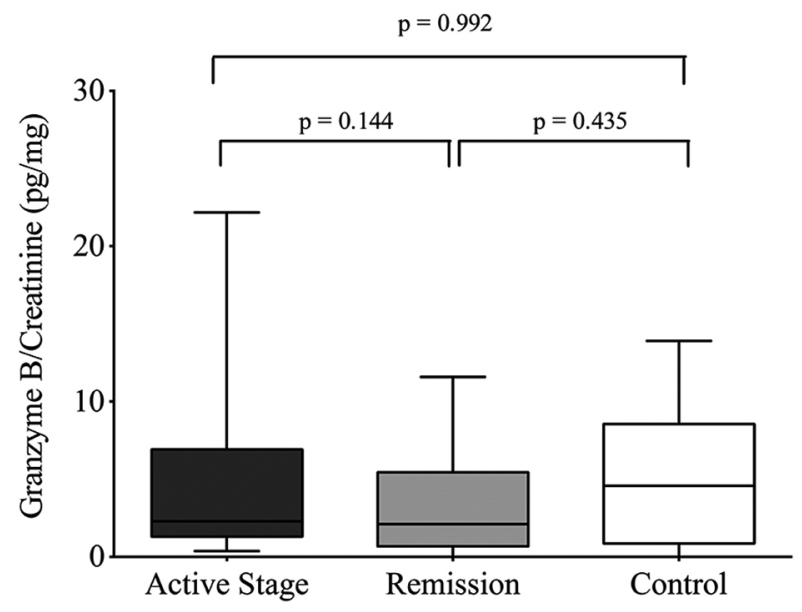

Figure 5. Urinary granzyme B levels of the study and the control groups

\section{Spearman's correlation analysis}

The granzyme B level was not included in the Spearman correlation analysis studies because we did not obtain statistically significant results for this marker. There were no correlations among the urine IL-13, CD80, CD28, MMP-2, and proteinuria levels. A statistically significant correlation was found only between the urine IL-13 and CD80 levels $(r=0.619$, $p<0.001)$.

\section{DISCUSSION}

In this study, we gave particular attention to the fact that the patients had not undergone any immunosuppressive treatment, including steroids, at the 
time of urine collection either when the active NS stage or in the remission stage. This was required because immunosuppressive treatment inhibits cytokine production. For example, CD4+ IL-13 mRNA expression is higher in unmedicated patients than in those taking steroids; in addition, steroids act to inhibit MMP production [25-27].

In 2004, Resier et al. evaluated the podocyte CD80 molecule in rats for the first time [10]. Their study introduced a new perspective of the MCD pathogenesis. According to these researchers, podocyte CD80 expression changed the actin structure of podocyte cells, resulting in nephroticlevel proteinuria. With respect to human studies, the presence of the CD80 molecule in the urine patients with active MCD was demonstrated by Garin et al. for the first time [11]. A probable reason for podocyte CD80 expression is rapid removal of dangerous toxins and by increased glomerular permeability [28]. It is well known that temporary proteinuria develops in patients with gram-negative sepsis [29]. However, this proteinuria is sustained in patients with MCD. This is likely due to failure of CD80 inactivation because of Treg dysfunction or impaired autoregulation by podocytes according to Shimada's "two-hit" hypothesis [30]. Similarly, we found increased urine CD80 levels in patients with active-stage MCD were significantly higher than those in both the remission and control groups.

Which factor or factors induces podocyte CD80 expression? One possibility is IL-13 [9]. IL-13 plays a key role in helminth infections and atopic diseases [8]. Although controversial, the association between MCD and atopy is generally accepted [6]. It has been demonstrated that human podocytes both express and respond to IL-4 and IL-13 [31]. We detected higher urine IL-13 levels in the active stage group than in the remission and control groups. Moreover, there was a statistically significant correlation between the IL-13 and CD80 levels. The most important study showing the relationship between IL-13 and MCD was performed by Lai et al [9]. These researchers demonstrated marked albuminuria, hypoalbuminemia, and hypercholesterolemia in rats that had undergone IL-13 gene transfection than in control rats. Moreover, histological examination of the transfected rats demonstrated a normal appearance by light microscopy, low IgM accumulation by immunofluorescence microscopy, foot process effacement of podocytes by electron microscopy, and upregulation of glomerular CD80 gene expression, as in MCD. Therefore, we think that our study supports the view that IL-13 is the cause of a contributing factor to the high urine level of CD80 during the active stage of MCD.

CD80 (B7-1) activates CD28 in humans (B7:CD28 pathway) [13]. Thus, $T$ cells become activated. Another function of the B7:CD28 pathway is the generation of Treg cells. These cells, which are also known as CD4+CD25+ T cells, suppress the function of effector T cells [13]. Both B7 (i.e. CD80 and CD86) and CD28 proteins are required for the development of these cells. Insufficiency in the development and function of Treg cells has been observed in both CD28- and B7-knockout rats [32] Not numerical, functional deficiencies in Treg cells have been demonstrated in MCD [18]. In rat models of crescentic glomerulonephritis and mesangioproliferative glomerulonephritis, CD28 superagonists, which enable increases in the number of Treg cells, have induced decreases in proteinuria, serum creatinine levels, and crescent formation [33,34]. We have shown that the active-stage urine CD28 levels in patients with MCD were high, along with the CD80 levels (i.e. the B7:CD28 pathway). This situation has led us to think that the human immune system modulates the number and/or function of Treg cells.

The balance between storage and destruction of the extracellular matrix is critical [35]. MMPs play an important role in achieving this balance, MMPs generally destroy many extracellular matrix proteins. This situation causes inflammation and fibrosis over time [36]. Although no inflammation is found in patients with MCD, it is known that proteinuria causes interstitial inflammation $[1,37]$. It has been shown that, MMP-2 is expressed by the podocytes of patients with proteinuria [38]. MMP-2 can destroy type-IV collagen molecules in the glomerular basal membrane $[39,40]$. In this study, the urine MMP-2 levels in children with active-stage MCD were higher than those in both the remission and control groups. Thus, we suggest that MMP-2 expression can be induced by inflammatory effect of proteinuria and this situation may cause or contribute to the proteinuria seen in patients with MCD.

Kaneko et al. demonstrated the absence of a $\mathrm{TH} 1$ or TH2 cytokine pattern in the pathogenesis of SSNS and suggested that cytotoxic T cells, NK cells, and/or monocytes/macrophages rather than TH cells may play roles in the pathogenesis using "three-color flow cytometry" [41]. Zeta chains on the surface of $\mathrm{T}$ and NK cells are responsible for intracellular signal transmission [42]. It has been shown that zeta chain expression decreases in NK cells in the active stage of SSNS and steroid-dependent 
nephrotic syndrome [21]. The decrease in the zeta chain expression indicates activation of the cell [43]. Therefore, this finding might be a sign of NK cell hyperactivity in the active stage [21]. In rat studies, it has been shown that granzyme/perforin-mediated pathways play a role in crescentic glomerulonephritis and that antiperforin antibodies can be used as treatment [44]. However, we demonstrated in the present study that granzyme B activity, which is also a sign of NK cell hyperactivity, was neither low nor high in the study and control groups. In our opinion, it is probable that during the active stage of MCD, NK cell activity only remains at the level of decreased zeta chain expression and there is no need for production of granzyme $B$ because of the absence of crescent formation.

In conclusion, in patients with MCD, the activestage urine IL-13, CD80, CD28, and MMP-2 levels were significantly higher than those in the remission and control groups. Abatacept, a fusion protein that blocks CD80 is used successfully in rheumatoid arthritis treatment, and its use in some autoimmune diseases is being investigated [45-48]. Additionally, abatacept decreases MMP-2 levels and enhances Treg function $[49,50]$. CD28 superagonists, which increase the number of Treg cells, have been successfully used in rat models of crescentic and mesangioproliferative glomerulonephritis $[33,34]$. In adults, lebrikizumab, an anti-IL-13 antibody, is successfully used in asthma treatment [51]. Treatment of anti-Thy2.2. nephritis, which is a rat model of mesangioproliferative glomerulonephritis (equivalent to Ig A nephropathy in humans), with the MMP-2 inhibitor BB-1101 decreases the extracellular matrix storage, glomerular hypertrophy, and proteinuria [52]. It is probable that in the future anti-CD80 and antiIL-13 antibodies, CD28 superagonists, and MMP inhibitors will either replace or be used as adjuncts to the long-used immunosuppressive treatments for steroid-resistant MCD. Therefore, we suggest that the roles of these treatment modalities in steroid and other immunsuppressive-resistant MCD should be investigated.

Conflict of interest: The authors declared no conflict of interest.

\section{REFERENCES}

1. Niaudet $P$, Boyer O. Idiopathic Nephrotic Syndrome in Children: Clinical Aspects. In Ellis D. Avner (ed.) Pediatric Nephrology. 6th ed. Springer-Verlag, Heidelberg; 2009, pp 667-702.

2. Shalhoub RJ. Pathogenesis of lipoid nephrosis: A disorder of T cell function. Lancet 1974;2:556-560.
3. Tejani AT, Butt K, Trachtman $\mathrm{H}$, et al. Cyclosporine A induced remission of relapsing nephrotic syndrome in children. Kidney Int 1988;33:729-734.

4. Ali AA, Wilson E, Moorhead JF, et al. Minimal change glomerular nephritis. Normal kidneys in an abnormal environment? Transplantation 1994;58:849-852.

5. Koyama A, Fujisaki M, Kobayashi M, et al. A glomeruler permeability factor produced by human $\mathrm{T}$ cell hybridomas. Kidney Int 1991; 40: 453-460.

6. Lagrue G, Laurent J. Allergy and lipoid nephrosis. Adv Nephrol Necker Hosp 1983;12:151-175.

7. Yokoyama H, Kida H, Tani Y, et al. Immunodynamics of minimal change nephrotic syndrome in adults $T$ and $B$ lymphocyte subsets and serum Ig levels. Clin Exp Immunol 1985;61:601-607.

8. Izuhara K, Arima K, Yasunaga S, et al. IL-4 and IL-13: Their pathological roles in allergic diseases and their potential in developing new therapies. Curr Drug Targets Inflamm Allergy 2002;1:263-269.

9. Lai KW, Wei CL, Tan LK, et al. Overexpression of interleukin-13 induces minimal change like nephropathy in rats. J Am Soc Nephrol 2007;18:1476-1485.

10. Reiser J, von Gersdorff G, Loos M, et al. Induction of B7-1 in podocytes is associated with nephrotic syndrome. J Clin Invest 2004;113:1390-1397.

11. Garin EH, Diaz LN, Mu W, et al. Urinary CD80 excretion increases in idiopathic minimal change disease. $J$ Am Soc Nephrol 2009;20:260-266.

12. Garin E, Mu W, Arthur JM, et al. Urinary CD80 is elevated in minimal change disease but not in focal segmental glomerulosclerosis. Kidney Int 2010;78:296302.

13. Abbas AK, Lichtman AH, Pillai S. Cellular and Molecular Immunology. Saunders Elsevier, Philadelphia; 2010, pp 194-198.

14. Urushihara M, Kagami S, Kuhara T, et al. Glomerular distribution and gelatinolytic activity of matrix metalloproteinases in human glomerulonephritis. Nephrol Dial Transplant. 2002;17:1189-1196.

15. Wasilewska AM, Zoch-Zwiers WM. Urinary levels of matrix metalloproteinases and their tissue inhibitors in nephrotic children. Pediatr Nephrol 2008;23:17951802.

16. Czech AK, Bennett M, Devarajan P. Distinct metalloproteinase excretion patterns in focal segmental glomerulosclerosis. Pediatr Nephrol 2011;26:2179-2184.

17. Afonina I, Cullen S, Martin SJ. Cytotoxic and noncytotoxic roles of the CTL/NK protease granzyme B. Immunol Rev 2010;235:105-116.

18. Araya C, Diaz L, Wasserfall C, et al. T regulatory cell function in idiopathic minimal lesion nephrotic syndrome. Pediatr Nephrol 2009;24:1691-1698.

19. Zhao DM, Thornton AM, DiPaolo RJ, Shevach EM. Activated CD4+CD25+ T cells selectively kill B lymphocytes. Blood 2006;107:3925-3932.

20. Cao X, Cai SF, Fehniger TA, et al. Granzyme B and perforin are important for regulatory $T$ cell-mediated suppression of tumor clearance. Immunity 2007;27:635-646. 
21. Musial K, Ciszak L, Kosmaczewska A, et al. Zeta chain expression in T and NK cells in peripheral blood of children with nephrotic children. Pediatr Nephrol 2010;25:119-127.

22. Nephrotic syndrome in children: prediction of histopathology from clinical and laboratory characteristics at time of diagnosis. A report of the International Study of Kidney Disease in Children. Kidney Int 1978;13:159165.

23. Schwartz GJ, Munoz A, Schneider MF, et al. New equations to estimate GFR in children with CKD. J Am Soc Nephrol 2009;20:629-637.

24. Viqnali DA. Multiplexed particle-based flow cytometric assays. J Immunol Methods 2000;243:243-255.

25. Yap HK, Cheung W, Murugasu B, et al. Th1 and Th2 cytokine mRNA profiles in childhood nephrotic syndrome: evidence for increased IL-13 mRNA expression in relapse. J Am Soc Nephrol 1999;10:529-537.

26. Yiğit O, Acioğlu E, Gelişgen R, et al. The effect of of corticosteroid on metalloproteinase levels of nasal polyposis. Laryngoscope 2011;121:667-673.

27. Weitoft T, Larsson A, Rönnblom L. Serum levels of sex steroids hormones and matrix metalloproteinases after intra-articular glucocorticoid treatment in female patients with rheumatoid arthritis. Ann Rheum Dis 2008;67:422-424.

28. Reiser J, Mundel P. Danger signaling by glomerular podocytes defines a novel function of inducible B7-1 in the pathogenesis of nephrotic syndrome. J Am Soc Nephrol 2004;15:2246-2248.

29. Pacquement H, Sinnassamy P, Quintana E, et al. Nephrotic syndrome and B leukemia. Arch Fr Pediatr 1989;46:741-742.

30. Shimada M, Araya C, Rivard C, et al. Minimal change diasease: a "two hit" podocyte immun disorder? Pediatr Nephrol 2011;26:645-649.

31. Parry RG, Gillespie KM, Mathieson PW. Effects of type 2 cytokines on glomerular epithelial cells. Exp Nephrol 2001;9:275-283.

32. Tang QZ, Henriksen KJ, Boden EK, et al. Cutting edge: CD28 controls peripheral homeostasis of CD4+CD25+ regulatory T cells. J Immunol 2003;171:3348-3352.

33. Takabatake Y, Li XK, Mizui M, et al. A superagonistic monoclonal antibody for CD28 ameliorates crescentic glomerulonephritis in wistar-kyoto rats. Mol Med 2011;17:686-696.

34. Miyasato K, Takabatake Y, Kaimori J, et al. CD28 superagonist-induced regulatory $\mathrm{T}$ cell expansion ameliorates mesangioproliferative glomerulonephritis in rats. Clin Exp Nephrol 2011;15:50-57.

35. Eddy AA. Molecular insights into renal interstitial fibrosis. J Am Soc Nephrol 1996;7:2495-2508.

36. Lenz O, Elliot SJ, Stetler-Stevenson WG. Matrix metalloproteinases in renal development and disease. J Am Soc Nephrol 2000;11:574-581.

37. Tobbli JE, Bevione P, Di Gennaro F, et al. Understanding the mechanisms of proteinuria: therapeutic implications. Int J Nephrol 2012;2012:546039.
38. Fanq Z, He F, Chen S, et al. Albumin modulates the production of matrix metalloproteinase-2 and -9 in podocytes. J Huazhonq Univ Sci Technoloq Med Sci 2009;29:710-714.

39. Baricos WH, Murphy G, Zhou YW, et al. Degradation of glomerular basement membrane by purified mammalian metalloproteinases. Biochem J 1988;254:609612.

40. Endo T, Nakabayashi K, Sekiuchi M, et al. Matrix metalloproteinase-2, matrix metalloproteinase-9, and tissue inhibitor of metalloproteinase- 1 in the peripheral blood of patients with various glomerular diseases and their implication in pathogenetic lesions: study based on an enzyme-linked assay and immunohistochemical staining. Clin Exp Nephrol 2006;10:253-261.

41. Kaneko K, Tuchiya K, Fujinaga R, et al. Th1/Th2 balance in childhood idiopathic nephrotic syndrome. Clin Nephrol 2002;58:393-397.

42. Irving BA, Chan AC, Weiss A. Functional characterization of signal transducing motif present in the T cell antigen receptor zeta chain. J Exp Med. 1993;177:10931103.

43. Bronstein-Sitton N, Wang L, Cuhen L, Baniyash M. Expression of the $T$ cell antigen receptor zeta chain following activation is controlled at distinct checkpoints. J Biol Chem 1999;274:23659-23665.

44. Fujinaka $\mathrm{H}$, Yamamoto $\mathrm{T}$, Feng $\mathrm{L}$, et al. Anti-perforin antibody treatment ameliorates experimental crescentic glomerulonephritis in WKY rats. Kidney Int 2007;72:823-830.

45. von Kempis J, Dudler J, Hasler $P$ et al. Use of abatacept in rheumatoid arthritis. Swiss Med Wkly. 2012;142: w13581.

46. Gallagher MP, Goland RS, Greenbaum CJ. Making progress: preserving beta cells in type 1 diabetes. Ann N Y Acad Sci 2011;1243:119-134.

47. Viglietta V, Bourcier K, Buckle GJ, et al. CTLA4Ig treatment in patients with multiple sclerosis: an openlabel, phase 1 clinical trial. Neurology 2008; 71: $917-$ 924.

48. Mok CC. Abatacept for systemic erythematosus: the outlook. Expert Opin Biol Ther 2012 ;12:1559-1561.

49. Weisman $M H$, Durez $P$, Hallegua D, et al. Reduction of inflammatory biomarker response by abatacept in treatment of rheumatoid arthritis. J Rheumatol 2006;33:2162-2166.

50. Álvarez-Quiroga C, Abud-Mendoza C, Doníz-Padilla L, et al. CTLA-4-Ig therapy diminishes the frequency but enhances the function of Treg cells in patients with rheumatoid arthritis. J Clin Immunol 2011;31:588-595.

51. Corren J, Lemanske RF, Hanania NA et al. Lebrikizumab treatment in adults with asthma. $\mathrm{N}$ Engl $\mathrm{J}$ Med 2011;365:1088-1098.

52. Steinmann-Niggli K, Ziswiler R, Kung M, Marti HP. Inhibition of matrix metalloproteinases attenuates antiThy 1.1 nephritis. J Am Soc Nephrol 1998;9:397-407. 